\title{
Identification Genetic of Soybean Mutant (Glycine max L. Merril) Based on Fatty Acid Characters Using Simple Sequence Repeat (SSR) Markers
}

\author{
Hafizha Hayati Barus $^{1 *}$, Eva Sartini Bayu², Diana Sofia Hanafiah ${ }^{3}$ \\ \{hafizha.hhb@gmail.com ${ }^{1}$, evagirsang61@gmail.com², dedek.hanafiah@yahoo.co.id ${ }^{3}$ \} \\ ${ }^{1,2,3}$ Agroteknologi Departement, Faculty of Agriculture, Universitas Sumatera Utara \\ *hafizha.hhb@gmail.com
}

\begin{abstract}
Soybean is one of the leading strategic food crop in Indonesia. Nowadays, people's need for soybeans is not only seen from the production aspects but also soybean nutrient contents, especially fatty acids. One of the ways to develop superior varieties of soybean with high fatty acids is through mutations. Seven soybean mutants selected M5 and M7 generation with high production character and resistance Athelia rolfsii Curz were genetically related to high fatty acids using SSR markers. DNA quality and quantity test results showed DNA purity between 1.12-2.13 with concentration between 15.4-97.9 $\mu \mathrm{g} / \mathrm{mL}$. The FAD2-2D locus is the gene candidate of the result by the $Q T L$ mapping used in this study to identify soybean genes related to linoleic acid characters. The results showed that the primer used was specific and polymorphic. Mutant soybeans tested have a high genetic diversity.
\end{abstract}

Keywords: mutant soybean, fatty acid, SSR markers

\section{Introduction}

Awareness of the importance of health encourages people to tend to choose vegetable food products as their nutritional needs. Soybean is a source of vegetable food, where every 100 grams of dry matter consists of 35 grams of protein, 35 grams of carbohydrates, 18-20 grams of fat, and other nutritional content [1]. Of the existing fat content, $85 \%$ of this amount consists of unsaturated fatty acids that are free of cholesterol [2]. Fat or oil is the source of energy compared to carbohydrates and protein. Where 1 gram of fat can provide $9 \mathrm{kcal}$ this means two times greater than carbohydrates and proteins that only produce $4 \mathrm{kcal}$ per gram [1]. In 2017, national soybean production only reached 538.728 tons but increased to 982.598 tons in 2018 [3]. The increased availability of soybean will support the need for soybean oil as an alternative to vegetable oils and a source of omega fatty acids [4].

One effort to develop superior soybean varieties high in fatty acids is through mutations. Mutations are genetic changes that occur in several numbers of genes or chromosome composition. The results of these mutations obtained mutant line, which is then selected based on the desired characteristics and are expected to be better than parents with the final goal to release superior varieties of soybeans [5]. Selection based on phenotypic observations, phenotypes are strongly influenced by the environment and require a long time because they 
have to wait for plants to grow and develop. Therefore the molecular markers approach needs to be considered to help an effective and efficient selection program [6].

The selection of markers that will be used in genetic analysis needs to find the desired objectives, sources of funds owned, facilities available, as well as the strengths and weaknesses of each type of markers [7]. One of the DNA markers based on polymerase chain reaction (PCR) is simple sequence repeat (SSR) markers that can identify the composition of the fatty acid-regulating allele in soybean mutant lines. SSR is specific loci, codominant and molecular markers based on repetitive DNA sequences that are spread in the genomes of eukaryotic living things [8]. The advantages of these markers are that they are abundant, highly polymorphic, codominant [9] based on PCR, able to detect polymorphic loci accurately [10] used for plant selection, analysis DNA fingerprinting, genetic mapping related to certain quantitative characters [11].

Research using microsatellite markers on soybean has been carried out to determine the location of the Quantitative Trait Loci (QTL) content of fatty acids including Bachlava et al. [12], Arjunrao [14]. FAD2-2D primers can be used as specific primers for the character of linolenic and linoleic acids in soybeans [12]. This study aims to determine the genetic diversity of mutant soybeans based on the character of fatty acids using SSR markers.

\section{Research Method}

This research was carried out at the Greenhouse and Molecular Genetics Laboratory of the Faculty of Agriculture, Universitas Sumatera Utara, September to Oktober 2019.

\section{Plant materials}

Soybean seeds obtained from M5 and M7 soybean mutant line selection based on high production characteristics and resistant Athelia rolfsii Curzi. They were M100-A17 (18/5), M200-A12 (6/5), M100-A25 (2/7), M100-A25 (3/4), M100-A25 (3/7), M100-A5 (31/1), M200-A11 (32/3), Anjasmoro as parents and Devon 1 as comparative variety. Seeds germinated, and the seedlings cultivated for DNA extraction in greenhouse. Twenty days after germination, young leaves from each plant were taken as much as 0.3 grams for DNA isolation.

\section{DNA Extraction}

The DNA isolation procedure was carried out based on the Cetyl Trimethyl Ammonium Bromide (CTAB) method of Orozco-Castillo et al. that was modified by the addition of PVPP and $\beta$-mercaptoethanol. After the DNA of each line is isolated, the DNA stock of each line is tested in quantity using a Nanodrop Spectrophotometer (Thermo Scientific, USA) and quality testing by electrophoresis method using Elektroforesis Power PAC 3000, Biorad.

\section{Quantity test of DNA soybean mutant}

DNA quantity testing was carried out using the spectrophotometer method using a Nanodrop Spectrophotometer (Thermo Scientific, USA) at wavelength $(\lambda) 260$ and $280 \mathrm{~nm}$ using $1 \mu \mathrm{l}$ of isolated and purified DNA stock. DNA has high purity if the ratio of absorbance values at wavelengths of $260 \mathrm{~nm}$ and $280 \mathrm{~nm}$ ranges from $1.8-2.0$ [13]. 


\section{Quality test of DNA soybean mutant}

DNA quality testing was carried out by standard method electrophoresis (Elektroforesis Power PAC 3000, Biorad) to see the presence of DNA on $1.5 \%$ agarose gel stained with ethidium bromide. Agarose weighed 1.2 grams and then dissolved in $80 \mathrm{ml}$ TAE buffer 1x. The solution was put into an erlenmeyer then heated using a hotplate and stirred with a magnetic stirrer so that the solution became clear and then cooled, added $0.5 \mu$ l ethidium bromide, stirring while reheating for 2 minutes. The solution is put into a gel well installed and allowed to condense for 60 minutes. The solidified gel was given $670 \mathrm{ml}$ TAE 1x solution (until submerged). Stock DNA that has been prepared is inserted into the gel well. After all, the gel well filled with gel wells next electrophoresis. Running electrophoresis was performed under 60 volts for 70 minutes. The Visualization of DNA that has been electrophoresed done by UV Transluminator and photographed using a gel documentation system (UV cambridge).

\section{PCR amplification}

Before running the PCR, each DNA sample was diluted by taking $3 \mu \mathrm{l}$ of DNA stock and

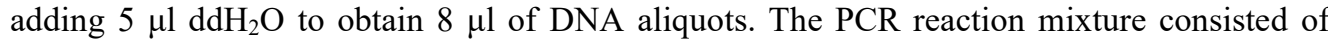

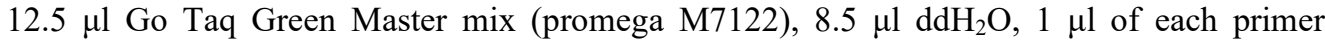
(forward and reverse) and $2 \mu \mathrm{l}$ DNA aliquots with a total volume of $25 \mu \mathrm{l}$ for one reaction. The PCR reaction was amplified in a thermal cycler applied bio system. Each sample was amplified with forward primers 5-GCCAAGGTGCATACATACGACA-3 and reverse 5GCCAACAATTTCTTTCCCCTCT-3 [14]. The optimization of the PCR condition was done by changing the annealing temperature of primers. Different annealing temperatures were tried to optimize the melting temperature of primers with help gradient PCR (BioRad and Eppendorf) and research Arjunrao [14] with some modification. PCR thermal cycling conditions were initial pre denaturation at $94^{\circ} \mathrm{C}$ for 5 minutes, followed by 35 cycles of denaturing at $94^{\circ} \mathrm{C}$ for 40 seconds, primer annealing at $55^{\circ} \mathrm{C}$ for 45 seconds, extension at $72{ }^{\circ} \mathrm{C}$ for 1 minutes, with a final extension at $72{ }^{\circ} \mathrm{C}$ for 7 minutes [14].

\section{Agarose gel electrophoresis}

DNA was analyzed by agarose gel electrophoresis using 1.5\% agarose gel (promega V3121). Electrophoresis was performed using $1 \times$ Tris-Borate EDTA (TBE) buffer and added $0.5 \mu \mathrm{l}$ of ethidium bromide (EtBr) at a volage of $60 \mathrm{~V}$ for $60 \mathrm{~min}$. The DNA bands were visualized and documented under UV light using gel documentation system (UV cambridge).

\section{Data analysis}

\section{Determination of Tape Size for PCR Results}

The size of the base fragment (base pair $=b p$ ) of the PCR product is determined using UVITEC Cambridge FireReader, the DNA fragment used as a standard measure of $100 \mathrm{bp}$ ladder DNA, the image data from the electrophoresis required by the program will be detected whether or not the band appears and try to use the markers that have been marked entered.

\section{Results and Discussion}

\section{Quantity test of DNA soybean mutant}

Testing the quantity of DNA of soybean mutant lines was performed using the spectrophotometer method. DNA purity is measured by looking at the absorbance ratio at 260 $\mathrm{nm}$ and $280 \mathrm{~nm}$. The following results of the DNA quantity testing of soybean mutant lines are presented in Table 1. 
Table 1. Purity and Concentration of DNA of soybean mutant strains

\begin{tabular}{clcc}
\hline No. & \multicolumn{1}{c}{ Sample } & Purity $(\AA 260 / 280)$ & Concentration $(\mu \mathrm{g} / \mathrm{mL})$ \\
\hline 1. & M200-A17 $(18 / 5)$ & 2.13 & 15.4 \\
2. & M200-A12 $(6 / 5)$ & 2.00 & 97.9 \\
3. & Devon 1 & 1.31 & 47.1 \\
4. & Anjasmoro & 1.81 & 25.0 \\
5. & M100-A25 (2/7) & 1.80 & 25.1 \\
6. & M100-A25 (3/4) & 1.94 & 18.6 \\
7. & M100-A25 (3/7) & 1.21 & 55.0 \\
8. & M100-A6 (31/1) & 1.24 & 44.8 \\
9. & M200-A1 (32/3) & 1.12 & 55.0 \\
\hline
\end{tabular}

Based on Table 1, it appears that the purity level of isolated DNA ranges between 1.12 2.13 and obtained DNA concentrations ranging from 15.4-97.9 $\mu \mathrm{g} / \mathrm{mL}$. The highest value was obtained from M200-A12 (6/5) with a concentration of $97.9 \mu \mathrm{g} / \mathrm{mL}$, and the lowest was M200-A17 (18/5), with a concentration of $15.4 \mu \mathrm{g} / \mathrm{mL}$. Good quantity test results are shown by absorbance values between 1.80-2.00 [13], such as Anjasmoro, M100-A25 (2/7), M100A25 (3/4) and M200-A12 (6/5). If the ratio is higher, it can be indicated the presence of impurities in the form of proteins, phenols or other strong contaminants its absorption at 280 $\mathrm{nm}$ as in M200-A17 (18/5), if the ratio is lower than the range of $1.8-2.0$, it can be indicated the presence of contaminants in the form of RNA in the samples tested as in Devon 1, M100A25 (2/7), M100-A25 (3/4), M100-A25 (3/7) [15]. DNA concentrations that are too little will affect the results of the documentation gel where the band will look thin or dim (Figure 1), if the absorbance value is not in the range 1.80 to 2.00 can cause smears due to the high content of polysaccharides and phenolic compounds [16]. Sufficient purity does not guarantee successful amplification of a gene, there are also other factors such as concentration that also need consideration [17].

\section{Quality test of DNA soybean mutant}

DNA quality testing aims to determine the level of purity of DNA isolation based on visualization of agarose gel electrophoresis. DNA quality testing was carried out on 7 DNA stock samples and 2 DNA stock comparative varieties. DNA quality testing was carried out by electrophoresis using agarose gel of $1.5 \%$ concentration on chamberwell containing $1 \mathrm{x}$ TAE buffer, with a voltage of 60 Volts for 70 minutes. The electrophoresis results are visualized under the UV Transilluminator. The following results of DNA quality testing of soybean mutant lines presented in Figure 1. 


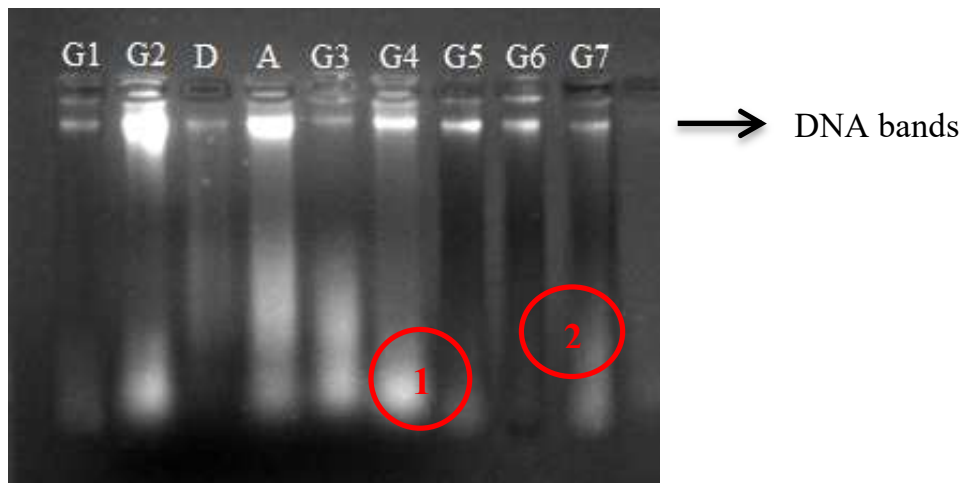

Fig 1. Electrophoresis test for the quality of DNA soybean mutant

$$
\begin{aligned}
& \text { Information : G1 : M100-A17 (18/5) G4 : M100-A25 (3/4) } \\
& \text { G2 : M200-A12 (6/5) G5 : M100-A25 (3/7) } \\
& \text { D : Devon } 1 \text { G6: M100-A5 (31/1) } \\
& \text { A : Anjasmoro G7 : M200-A11 (32/3) } \\
& \text { G3 : M100-A25 (2/7) }
\end{aligned}
$$

Based on Figure 1, all DNA samples tested show the presence of DNA bands (arrows) bright and thin. However, in samples M200-A12 (6/5), Anjasmoro, M100-A25 (2/7) and

thought to be an impurity or contaminant [15] that was carried during the isolation process or could also be degraded DNA in the DNA isolation process [18]. Based on DNA quantity test results, samples of M200-A12 (6/5), Anjasmoro, M100-A25 (2/7) and M100-A25 (3/4) have good purity (table 1), but the DNA quality test found smears. This is caused by technical errors when injecting into a chamberwell. Solihah reported smears on DNA bands can also be caused by repetitive DNA piping so that DNA will be cut off. DNA quality test results showed satisfactory results. This research used CTAB method of Orozco-Castillo et al. that was modified by the addition of PVPP and $\beta$-mercaptoethanol so produced good quality DNA. The use of polyvinylpolipirolidone (PVPP) antioxidants and mercaptoethanol in extraction buffers can produce good quality DNA. PVP and mercaptoethanol will reduce phenolic compounds that can damage the quality of DNA [19].

\section{Visualization of DNA Amplification Results by the Electrophoresis Method}

DNA amplification of 7 soybean mutant lines and 2 comparative varieties for fatty acid characters was carried out using 1 specific fatty acid primers namely FAD2-2D and then electrophoresed using $1.5 \%$ agarose gel, voltage of $60 \mathrm{~V}$ for 60 minutes. The electrophoresis results were then visualized under the UV Transilluminator. Visualization of agarose electrophoresis results of $1.5 \%$ of each primer on 7 samples and 2 comparative varieties can be seen in Figure 2. 


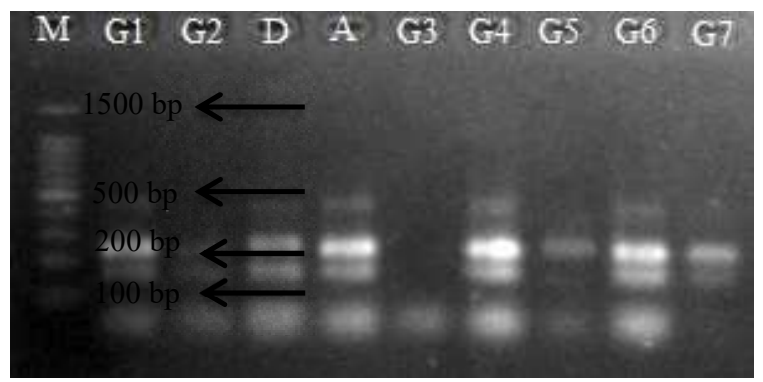

Fig 2. Band profile of 7 soybean mutant lines and 2 comparative varieties using primer FAD2-2D

$$
\begin{aligned}
& \text { Information : } \\
& \text { M : Marker Ladder } 100 \text { bp G3 : M100-A25 (2/7) } \\
& \text { G1 : M100-A17 (18/5) G4 : M100-A25 (3/4) } \\
& \text { G2 : M200-A12 (6/5) G5 : M100-A25 (3/7) } \\
& \text { D : Devon } 1 \quad \text { G6 : M100-A5 (31/1) } \\
& \text { A : Anjasmoro G7 : M200-A11 (32/3) }
\end{aligned}
$$

The primer FAD2-2D showed amplification in 8 samples tested. For several samples that were not successfully amplified, the PCR procedure was repeated by optimizing the annealing temperature, the final result was that there was 1 DNA sample that did not successfully amplify, M100 A25 (2/7) sample. Band pattern is heterozygous, which is the number of bands that appear as much as two in several samples tested with a band size range between $158 \mathrm{bp}$ to $247 \mathrm{bp}$. The largest band size in the M100 A17 (18/5) sample is $247 \mathrm{bp}$, while the smallest band size in the M200 A11 (32/3) sample is 158 bp. Primer FAD2-2D was used in the previous studies by Arjunrao [14] and Bachlava at al., [12] and showed the size of the amplicon of $220 \mathrm{bp}$. Bachlave et al., [12] reported this isoform (FAD2-2D) of FAD6 gene was associated with linoleic content [14].

The success of doubling specific sequences to the target DNA can influence by several factors, including the primary suitability of the target DNA, the annealing temperature used, and the purity of extracted DNA [15]. The results showed that there was a mismatch of base pairs of M100 A25 (2/7) DNA samples with nucleotide bases in primer FAD2-2D so that during the amplification process, the nucleotide bases could not stick to the target sequence. Unamplified DNA samples indicate no banding patterns when visualizing agarose gel electrophoresis under UV Transilluminator.

Amplification of soybean mutant DNA using one specific fatty acid primer shows that the marker can amplify DNA by producing two banding patterns with a percentage of polymorphism of $100 \%$. Polymorphism indicated by the presence of two or more alleles in a population [20]. The locus can be said to be polymorphic if it has more than one allele [21], and if the frequency of occurrence is less than 0.99 , it means that one allele can appear on one accession but no other accessions appear [22]. Conversely, genes are said to be monomorphic if they do not meet predetermined polymorphic criteria [20]. The high level of polymorphism produced from the primer FAD2-2D indicates that the genetic diversity of the mutant soybeans tested was relatively high. 


\section{Conclusion}

DNA quality and quantity test results showed DNA purity between 1.12- 2.13 with concentration between 15.4-97.9 $\mu \mathrm{g} / \mathrm{mL}$. Primer FAD2-2D was specific primer and capable by producing polymorphic bands so mutant soybeans tested have a high genetic diversity.

\section{Reference}

[1] Isa, I.: Penetapan Asam Lemak Linoleat dan Linolenat Pada Minyak Kedelai Secara Kromatografi Gas. Saintek Vol 6. No 1 (2011)

[2] Pryde, E. H.: Composition of Soybean Oil, Hand Book Of Soy Oil Processing and Utilization (1980)

[3] Kementrian Pertanian Republik Indonesia.: https://www.pertanian.go.id (2019)

[4] Setyawardhani, D. W., A. W. Anggraeni, I. Wulandari.: Peningkatan Konsentrasi Asam Lemak Tak Jenuh Dalam Minyak Kedelai dengan Metode Fraksinasi Kompleksasi Urea. ISSN : 1412-9612 (2012)

[5] Zuyasna, Chairunnas dan Zuraida.: Seleksi In Vitro Genotipe Mutan $\left(\mathrm{M}_{3}\right)$ Kipas Putih Untuk Toleransi Terhadap Kekeringan. J.Floratek 12 (2): 122-131 (2017)

[6] Lestari, E. G., Asadi S., Hutami, R. Purnamaningsih, S. Rahayu.: Prosiding Seminar Hasil Penelitian Tanaman Aneka Kacang dan Umbi. Balai Besar Penelitian dan Pengembangan Bioteknologi dan Sumber Daya Genetik Pertanian. Bogor (2016)

[7] Azrai, M.: Sinergi Teknologi Marka Molekuler Dalam Pemuliaan Tanaman Jagung. Jurnal Litbang Pertanian, 25(3) (2006)

[8] Mullis KB.: The Unusual Origin of the Polmerase Chain Reaction. Scientific American 3:56-65 (1990)

[9] Saghai-Maroof MA, Biyashev RM, Yang GP, Zhang Q, Allard RW.: Extraordinarily Polymorphic Microsatellite DNA in Barley Species Diversity, Chromosomal Location and Population Dynamics. Proc Natl Acd Sci. 9:5546-5470 (1994)

[10] Chawla, H. S.: Introduction to Plant Biotechnology. Science Publishers. Inc. New Hampshire. USA (2002)

[11] Madesis, P., I. Ganopoulos, and A. Tsaftaris.: Microsatellites: Evolution and Contribution. In: S.K. Kantartzi (Ed.). Microsatellites Methods and Protocols. Humana Press, Illinois, USA (2013)

[12] Bachlava, E., R. E. Dewey, J. W. Burton, A. J. Cardinal.: Mapping Candidate Genes for Oleate Biosynthesis and Their Association With Unsaturated Fatty Acid Seed Content in Soybean. Mol Breeding (2009) 23 : 337-347 (2009)

[13] Sambrook, J., Fritsch, E.F., and Maniatis.: Moleculer Cloning a Laboratory Manual. Cold Spring Harbour Laboratory. CSH. New York. Evolution, 51:1764-1772 (1989)

[14] Arjunrao, W. K.: Molecular Marker Analysis of Soybean (Glycine Max (L.) Merr) Genotypes For Pufa Content. Disertation. Agricultural Biotechnology. India (2016) 
[15] Suparningtyas, J. F., O. D. Pramudyawardhani, D. Purwoko, T. Tajuddin.: Analisis Filogenetik Beberapa Klon Karet Dengan Marka AFLP (Amplified Fragment Length Polymorphism). Volume 5 No 1. ISSN 2548 - 611X (2018)

[16] Syahputra, I.: Validasi Keturunan Kelapa Sawit Material Genetik Pt Socfindo Berdasarkan Marka SSR (Simple Sequence Repeats). Tesis. Universitas Sumatera Utara, Medan (2016)

[17] Latif, A. A., G. Osman.: Comparison of Three Genomic DNA Extraction Methods to Obtain High DNA Quality from Maize.

[18] Mulyani, Y., A. Purwanto., I. Nurruhwati.: Perbandingan Beberapa Metode Isolasi DNA untuk Deteksi Dini Koi Herpes Virus (KHV) Pada Ikan Mas (Cyprinus carpio L.). Fakultas Perikanan dan Ilmu Kelautan, Universitas Padjadjaran. Jurnal Akuatika Vol. II No. 1/Maret Tahun (2011)

[19] Syafaruddin, E. Randriani, T. J. Santoso.: Efektivitas dan Efisiensi Teknik Isolasi dan Purifikasi DNA Pada Jambu Mete. Buletin Ristri Vol 2 (2) (2011)

[20] Diyono, R.: Karakteristik Ukuran Tubuh dan Polimorfisme Gen Gh, GHRH dan PIT-1 Pada Populasi Kerbau di Banten. Tesis. Institut Pertanian Bogor. Bogor (2009)

[21] Goldstein, D.B. and C. Schlötterer.: Microsatellites: Evolution and Applications. Oxford University Press, New York, 368p (1999)

[22] William J.G.K., A.R. Kubelik, K.J. Livak, J.A. Rafalski' and S.V. Tingey.: DNA Polymorphisms Amplified by Arbitrary Primers are Useful as Genetic Markers. Central Research and Development Department and 'Agricultural Products Department, E.l. du Pont de Nemours \& Co., Inc., Experimental Station, Wilmington, DE 19880, USA (1990) 